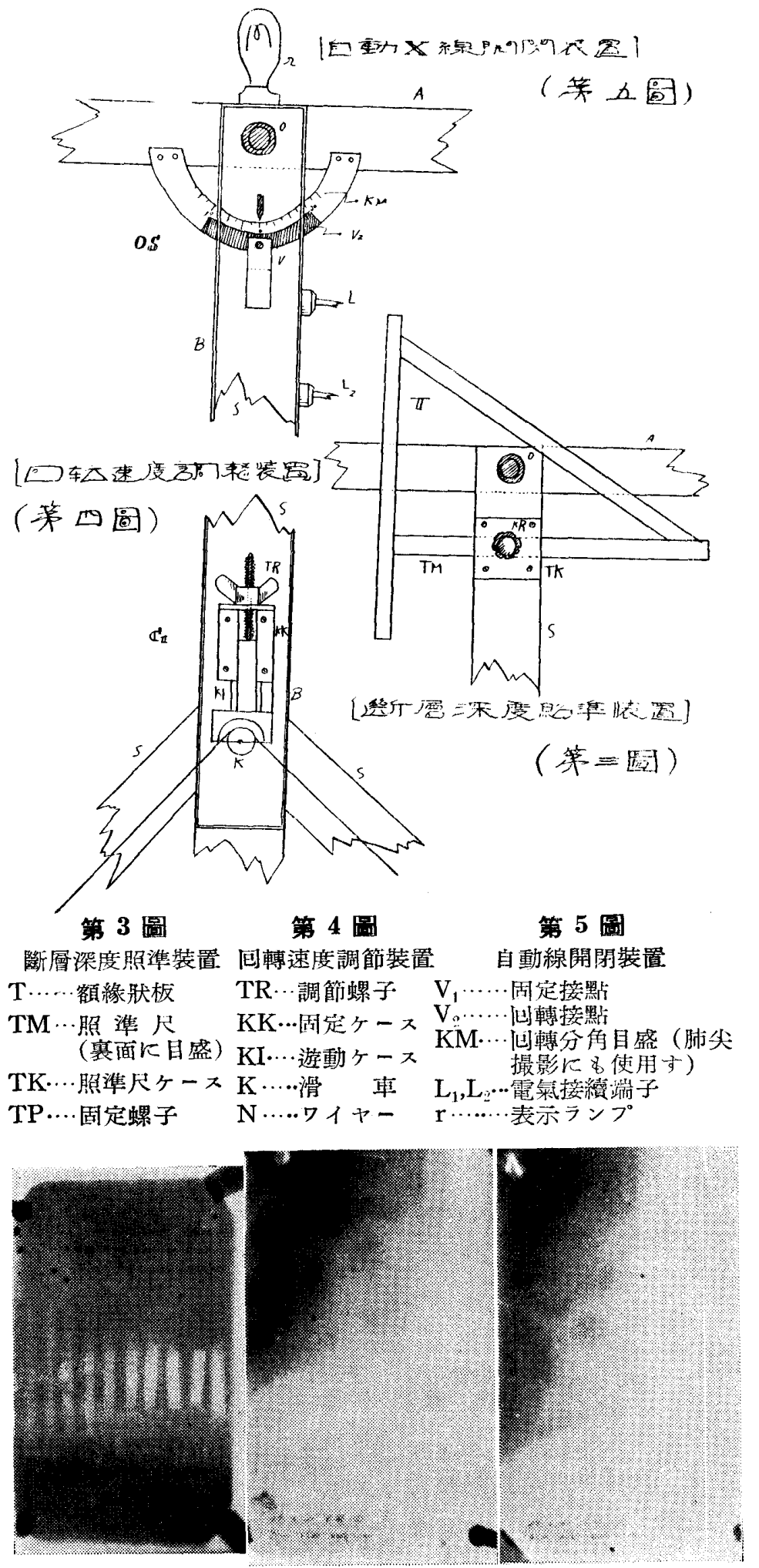

第 6 圖
カセッテ保持器住斷面, フィルム間の距離 $7 \sim 20 \mathrm{~cm}$ の間側面の目盛りに依り調節可能 で螺子にて固定出來る。文保持器の下部には 重錘を附し絕元ず垂直を保つ事が出來る。

C 斷層深度照準器 (第 3 圖)

額秝呮で, 額面は上質ベニヤ板を使用, 額 面上に各フィルムの大をさを記入，被弿體の 部位を正確は合せ背部を密着さす事が出來 る。

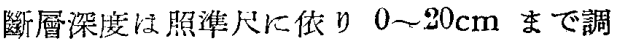
節叮能，螺子火て固定出來る。

高さ䌿名轉椅子式で，上下 $20 \mathrm{~cm}$ 調節何能 である。

D 间轉速度調節器 (第 4 圖)

粗調節汪重垂に依り，密調節脑1分ワイヤ 一の兩湍圭アームの中心軸上り等距離に固定 し，3個つ滑車をスタチーフに着裝，圖り如 く中間滑車を上下する事に上り調節出來る。

$\mathrm{E}$ 自動 X 湶開開器 (策 5 圖)

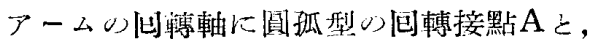

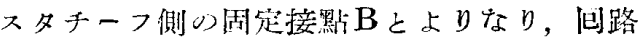

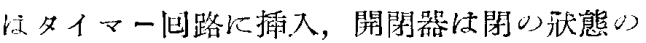
閒表示ランプが點灯し X線を放射する。

\section{組立啳のテスト}

粗立後先ず，フアントーム飞依るテストの 結果切れる自信が着いたので，患者（胸厚21 $\mathrm{cm})$ を撮影してみを。條件は F.P.D. $80 \mathrm{~cm}$ $60 \mathrm{kVp} 12 \mathrm{~mA} 4.0 \mathrm{Sec}$ で充分黑化度のある摩

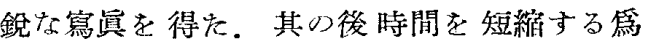
K，極光 HS 增感紙使用して $1.5 \sim 3.0 \mathrm{Sec}$ で確筫に撮影出來るようになった。

份本裝置飞依 り, 肺尖撮影学簡單且確筫に 行ら事が出來る。（第 5 圖參照）

\section{結空}

試作㣪の結果として普段使用する事が少な 、携帶用裝置を有效に使用出來，裝置ば總て 自動的である篇，籣單尔操作に依り充分彰斷 鄨值のある舄道を得る事が出來たので報告す る.

終りに本裝置試作にあたり御指導を賜つた 武田教授, 植殿博士に深謝し, 終始御㶸力下 さつ䓨院西信先生外諸先生及び，䚣田學兄 に厚く感謝する。

\section{熊考盗料}

東芝 X 線資料（第 3 輯）

大日本レントゲン資料（第 5 號）

\title{
携帶用 $\mathrm{X}$ 線裝置を利用した斷層撮影裝置の試作
}

九州勞茨病院

熊 谷䇥 義 


\section{I 緒 言}

最近結核對策が重要課題として取り上げられ，それ

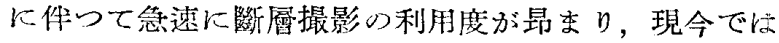
結核の診影亡治療り完壁を期する方めには不可缺の存 在となってしまつた。然し乍ら諸種の條件に制秎され て，之心躍入に困難を感ずるので，携帶用 X 湶裝置

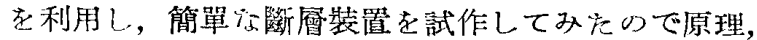
構造の概略，機能檢查結果，他裝犆との比較結果を逰 ベ标い.

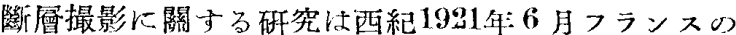
A. E. M. Bocage が 3 種類の方式老考案しにのに始 まり，其り後幾多の先人に上つて研究が續けられたが 現在で沬 G. Grossman のものが代表的なるのとされ ている椾である。

本邦飞於て子容地韶太郎，藤本慶治，西川豊藏，浑

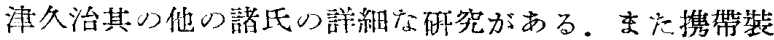

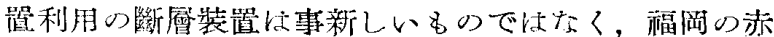

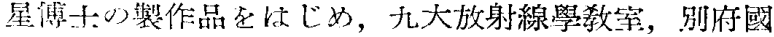
立我川病院等に於て System 次違らが製作使用にててい

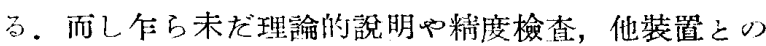
比較等の發表が行われてい应い様である。

\section{II 本論}

A 原理

1. 摡 念

断層撮影裝置り概念としては G. Gross manが「焦點をある軌道に沿つて湟動せし

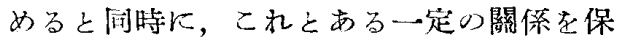
たせながら Film 上の一定點をある軌道に 沿つて運動せしめ，被藛體を截る一平面上 の任意り點が Film 面上に投ずる影と Film との相涂速度を常に零ならしめんとする裝 置」といつている。

さ. 相關運動心條件

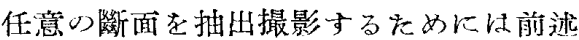
৩如く管球一基準他輼軸-Film の相關運 動が必装であるが，これには次の條件がい る。

1）基準间䦄軸の位置及力向が撮影間不

動であつて上下左右に移動しないこと。

口）管球焦點一基準何轉心-Film が常に一直湶 上にあり，其の距離の比が一起であること。

第 1 圖に於て $\frac{R}{R+r} \cdot \frac{R}{r}$ 一定

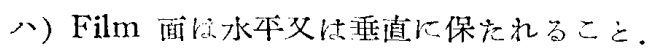

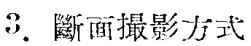

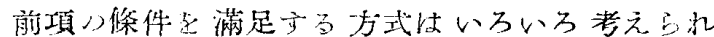
3 .

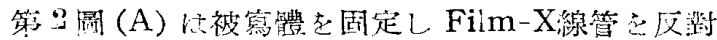

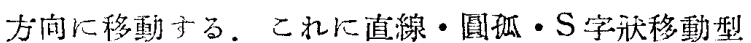
があ当。

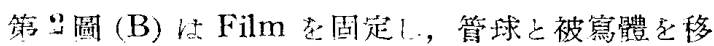
動させる。

現在實用化されているものは（A）のSystemを採
（第 1 圆）

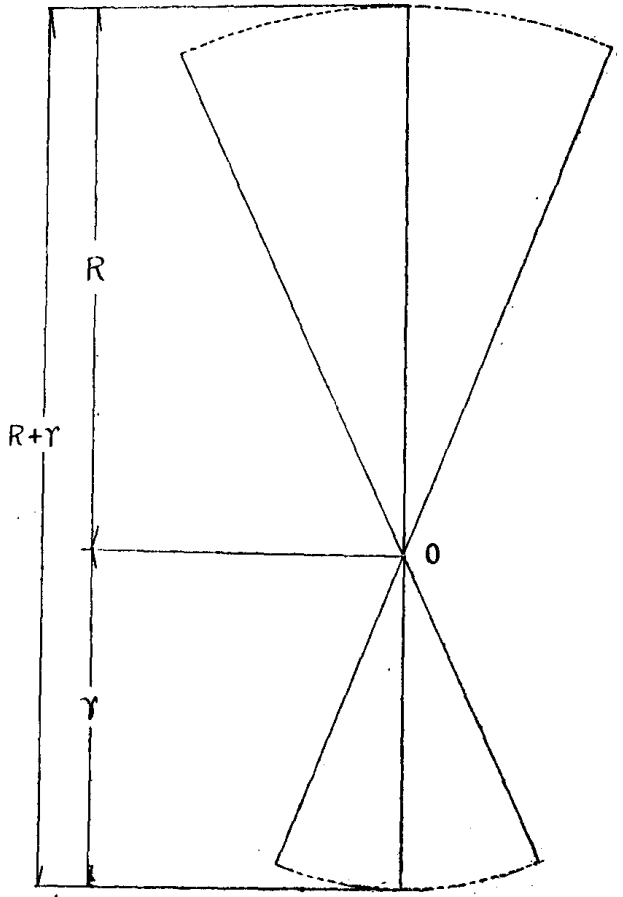

(第 2图)

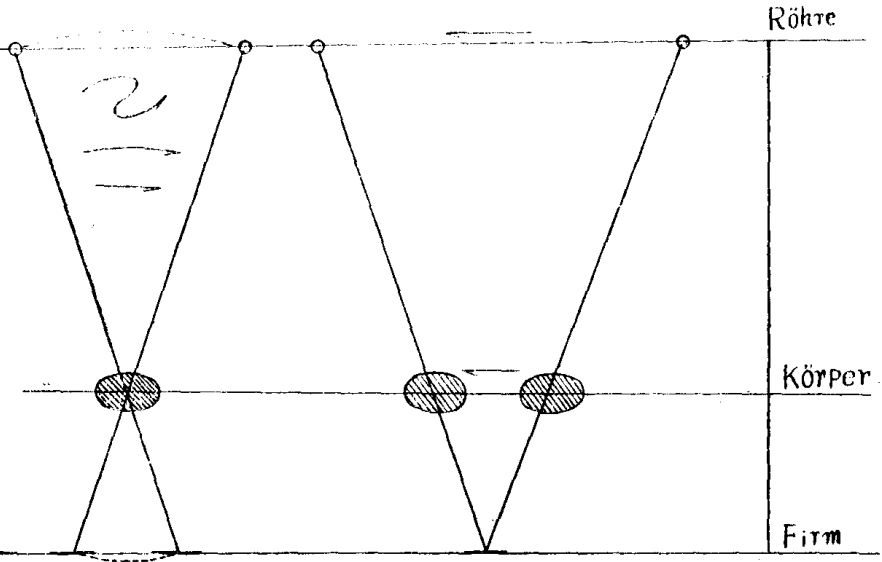

(A)

(B)

（第 1 表）

\begin{tabular}{|c|c|c|c|c|}
\hline Iaker & $\begin{array}{l}\text { 焦點心 } \\
\text { 軌 道 }\end{array}$ & $\begin{array}{l}\text { Film } \\
\text { の軌 道 }\end{array}$ & $\begin{array}{l}\text { 照準 } \\
\text { 斷面 }\end{array}$ & 䋫面照準法 \\
\hline $\begin{array}{l}\text { Sanitas } \\
\text { (Tomo) }\end{array}$ & $\begin{array}{l}\text { 一华面内 } \\
\text { 心㲀弧 }\end{array}$ & $\begin{array}{l}\text { 焦點軌道之 } \\
\text { 闰一本面内 } \\
\text { 心圆弧 }\end{array}$ & 水本 & 包轉軸を移動 \\
\hline $\begin{array}{l}\text { Siamens } \\
\text { (Plani) }\end{array}$ & 一然面内 & 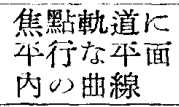 & 重直 & 被寫體在移動 \\
\hline 國海A社 & $\begin{array}{l}\text { 圆筒面队 } \\
\text { O曲線 }\end{array}$ & $\begin{array}{l}\text { 焦點軌道之 } \\
\text { 间軸圓筒面 } \\
\text { 内曲線 }\end{array}$ & 水平 & 回轉軸を移動 \\
\hline 國社社 & 水平直線 & 水平直線 & 水本 & 问轉軸を移㫫 \\
\hline
\end{tabular}

(深津改漞)

用しているが各メーカーの製品结第1表の通りであ 当。 
4. 運動角之諸關俰

1) 抹消像のづれ

斷面裝置では焦點と Film の移動によつて斷面 外にある全ての點は Film 除影に「づれ」を生じ. 像の尖鋔度を失ら結果抹殺されるのであるが，此 の影像り「づれ」は運動角に左右される。

「づれ」の長さ在 $a$ とすれば

$$
a=(R+r) \frac{2 v \sin \theta}{R \cos \theta-y}
$$

但L $R$ 一斷面胉準間距離

$\mathrm{r}$ 一瞇面, Film 間距離 y-一断面，抹消物體間距離 $\theta$ 一運動角度の $1 / 2$

$y$ の距離は非常に小さいので無視し $R \cos \theta-3 \div$ $R \cos \theta$ と被く と

$$
a=\frac{(R+r)}{R} 2 y \tan \theta
$$

又一方この物體の Film 上の投影の長さを $l$ とす れば

$$
l=l_{0} \frac{R+r}{R}
$$

但し $l_{0}$ 一物體の (2) と (3)の比老とつて $g$ とすると 長さ

$$
g=\frac{a}{l}=\frac{2 y \tan \theta}{l_{0}}
$$

此のgの值を抹消度といつて椄面骍置の性能を表 わす重要尔要素とされ，gの大交る程性能が是い といらことになる。此のgを大ならしめる條作と して焦點と Film め運動角がなるだく大いこと が必要である。

口）Film 面に荳するX湶入射角の黑化度に及店 寸影芗響

然し乍ら運動角が大となり Film 面に對して斜 めにX線が當ると第 3 圖で見る憡にとの實效的の

(茅 3 (日)

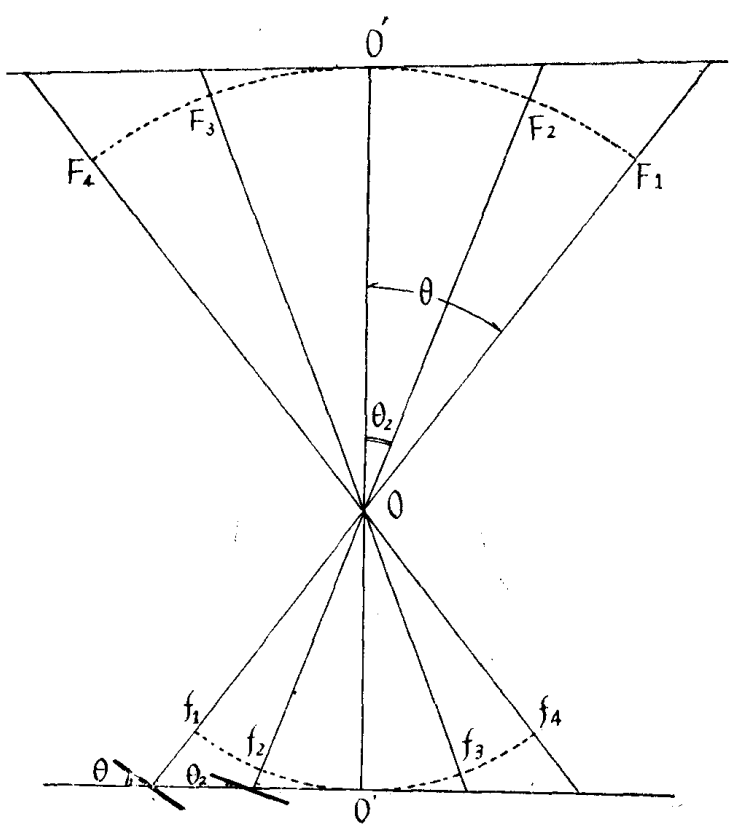

强さは入射角 $\theta$ の $\cos \kappa$ 比例して减衰する。 第 表で見る通り其の强さは $\theta=0$ のとを 1 とすれば $40^{\circ}$ の場合住 0,766 儿減弱しているこ とが分る。此の樣に選動角に上つて赛效 X 線量 が減弱さ九る。

（第 2 表）

\begin{tabular}{c|c}
$\theta$ & 1 \\
\hline $5^{\circ}$ & 0.9969 \\
10 & 0.9848 \\
15 & 0.9659 \\
20 & 0.9897 \\
30 & 0.8660 \\
40 & $0.7660 \quad$ \\
& \\
\end{tabular}

5. 鮮 銳 度

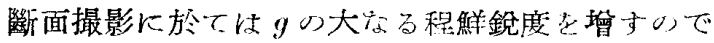
あるが，其の他明瞭度に關你する二・ジ要溸に就 て檢討を加える.

1）䁈效焦點の大をさ之撮影距離

管球焦點の大きさが鮮銳度に關係することは㖓 面裝置を論ずる迄もなく一般裝置に於て㗅知心事 貫であるが一般的にボケの大きさ $B$ は炏式によつ て表わされる。

但し $S=$ 實效焦點つ大さ

$T=$ 目的物 Film 間距噍

$D=$ Fokus, Film 間距離 $\theta=\mathrm{X}$ 線入射解

$$
B=S \frac{T}{D-T} \cdot \frac{1}{\cos \theta}
$$

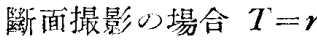

$$
\begin{aligned}
& D=R+r \text { であるから } \\
& \qquad B=S \cdot \frac{r}{R} \cdot \frac{1}{\cos \theta}
\end{aligned}
$$

此の式によつて分る栐に管球・焦點度 $r / R$ 者出

\begin{tabular}{|c|c|c|c|c|}
\hline \multicolumn{5}{|c|}{$B(\mathrm{~mm})$} \\
\hline \multirow[t]{2}{*}{ 管球容量 } & 實效焦點 & \multicolumn{3}{|c|}{$r / R=\frac{1}{5}$} \\
\hline & \multirow{2}{*}{$\stackrel{S}{(\mathrm{~mm})}$} & \multicolumn{3}{|c|}{ 焦點移動牦度 } \\
\hline $\mathrm{kW}$ & & $0^{\circ}$ & $80^{\circ}$ & $50^{\circ}$ \\
\hline 2 & 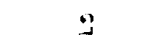 & 0.4 & 0.41 & 0.44 \\
\hline 4 & 3 & 0.6 & $0.6 \mathrm{~s}$ & 0.66 \\
\hline 6 & 4 & 0.8 & $0.8 \%$ & 0.88 \\
\hline 10 & 5 & 1.0 & 1.0 .1 & 1.14 \\
\hline
\end{tabular}
來吕だけ小さく，且管球一基準四轉軸閒い距離々 大とし基準何轉軸一Film 間の距離を小さくすれ ばボケが少くなる事が分る。

此の點 SDO-』を使用でをれば好都合である。 各管球のボケの大きさは第 3 表の通りである。

(第 3 表)

(深津) 
6. 考 察

以上の检討に更に装置の電氣的容量を加味して考

えると，

(1) 運動角は出來るだけ大にしなければならぬが線 量心減弱を考慮に入れると一定心限界があること．

(2) 管球一基準何轉軸間距離は田來るだけ大である 方が良いが製作機構上一定心限界がある。

(3) 包轉軸一Film 間の距離は出來るだけ小でなけ ればならぬが人體の厚さと製作機構上かなり大き

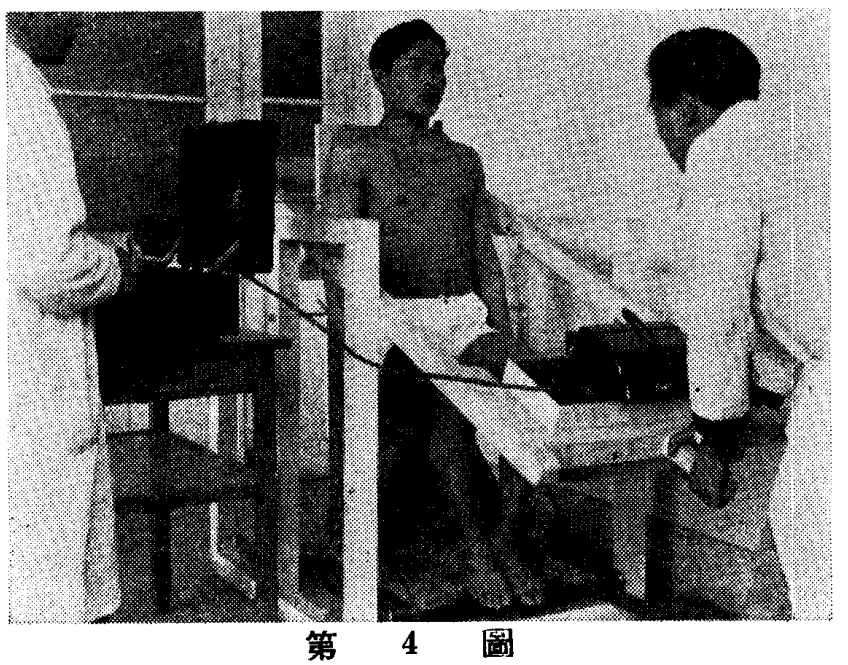

くなる事を免れない。

B 試作裝置

考察の結果試作した裝置の外觀は第 $\mathbf{4}$

圖の通り。

1. 支持台及狍轉支柱

矩形木製の組合せ台上に 6 本の支桂 を值立させ，そ心上部は2本の腕木に よつて堅审に固定している。此の中央 部に包轉支杜を固定する。ここを軸と して间轉しスここが斷面軸となる。间 轉支桂はその一端に Film 支持器を垂 直に取り附他端に携帶用 X線裝置容 器を備えつける。最大運動角を $50^{\circ}$ と し手動によつて圓孤運動を行う。管球 焦點一斷面軸距離 $100 \mathrm{~cm}$ 一定.

2. X 線裝置

Matsuda PK20 型携帶用X線裝㯰を $\mathrm{X}$ 線裝置 容器に收容する。この裝置 はSDO-2 型X 線管を使用している。 3. Film 支持器

包轉支桂の一端に取りつけられた Film 支持器任他端定 補助可轉支柱に 取りつけられ Film 醉が常に垂直に保 たれたま匜轉渾動を行らことが出來

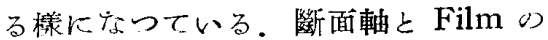
距離、 $20 \mathrm{~cm}$ 一定.

4. 被舁體固定裝置

被寫體を坐位にして撮影する場合， 被寫體の動搂圭防止するため第 5 圖の 如主鐵骨製 L字型移動車を作 り，その 上にベニヤ板の上張りをなし，下面に
車輪がついていてレールの上を移動する。な扣此の 固定器は下部後面に移動用のめねぢを出し，之は支 持台に取付けられたをねちと連結し，把手によつて 自由に被寫體を移動させ断厤面の任意選擇が出來る 㥞になつている。把手 2 回轉で $1 \mathrm{~cm}$ 移動。

5. 操 作

1）患者を固定裝置に溗せ，背部を固定板に密着 させる。

口）四轉支桂を支持台と水平に保つて患者の撮影 位置老㑢定する。

八）撮影を開始しょ5とするとを回轉支杜を最高 角度迄舉げる。

二）患者に呼吸停止老命じ，徐々に间轉支桂圭下 方に下げて行く之同時にX線孝入れる。

ホ）最底位で包轉支杜が停止せんとする寸前にX 線老切当。

へ）间轉支杜が最底位で停止し患者に呼吸を命ず b.

ト）撮影條件 一次電流 $20 \mathrm{~A}, 4$ ６＂，電壓計ナ シ.

C 工作精度蒜驗

精度試驗老行らために次の㥞な方法をとつた。

弑驗板は第 6 圖 (A) の样に不板七反直徑 $0.9 \mathrm{~mm} の$ 針金を韭つた\&のと第 6 圖 B の样に直徑 $4 \mathrm{~mm}$ の銅 球を $10 \mathrm{~mm}$ の等間隔に木板に埋めこみ且木板は $45^{\circ}$
(莱5 田)

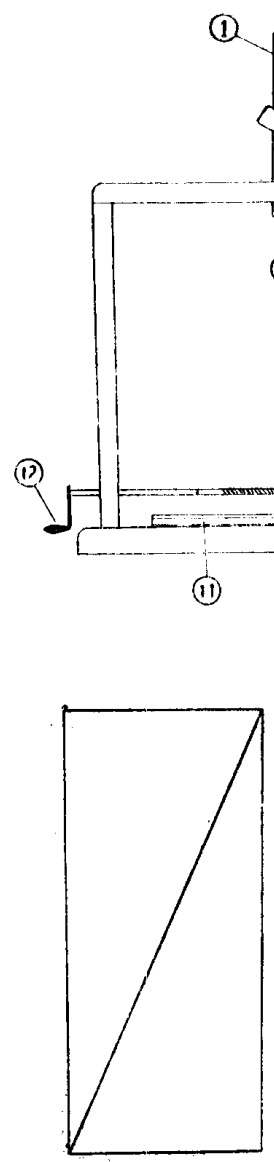

(A)

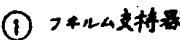

(2) 断面损示株

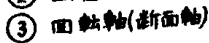

(4) metit

(5)专样台

(6) 球家娄

(7)四枟梅子

(8) 禣助的㗅柱

(9) 固妾板

(10) +4

(iii) - ル

(12)格野郅手
(8)

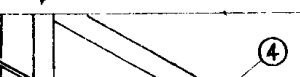

(9)

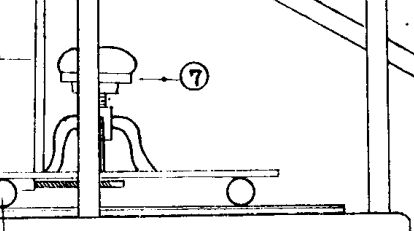

(10)
(茅6

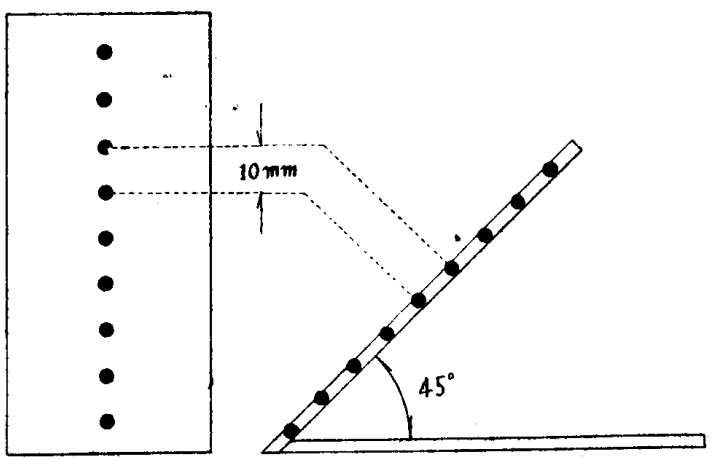

(B) 
の角度をもつたるのを使用した。

1) X線管の位置圭始動位置, 中央位置, 終此位置 の 3 ケ所で前述の試驗板を被寫體として撮影を行 斻。

2) A 角度をつけて同栐撮影を行つ范。

3) 狄に两板を X 線管を連續移動しで撮影を行つ 就.

4) 結 果

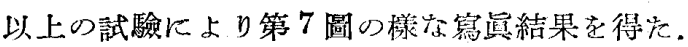
普通行われている数字の庥定切つて所裂の数字が 撮影出來をから此の裝置は完全であるといら様な試

第 7 圖

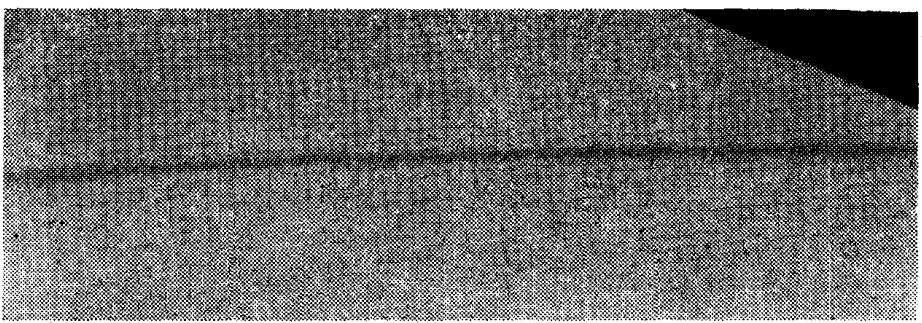

直湶を平面に犆を始動中央，終上の3ケ所で摄影

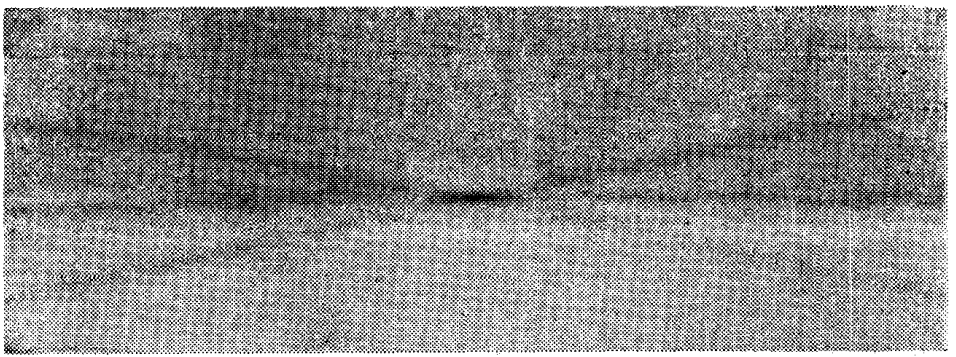

直線に䄪 $30^{\circ}$ 角度をつけて同上撮影

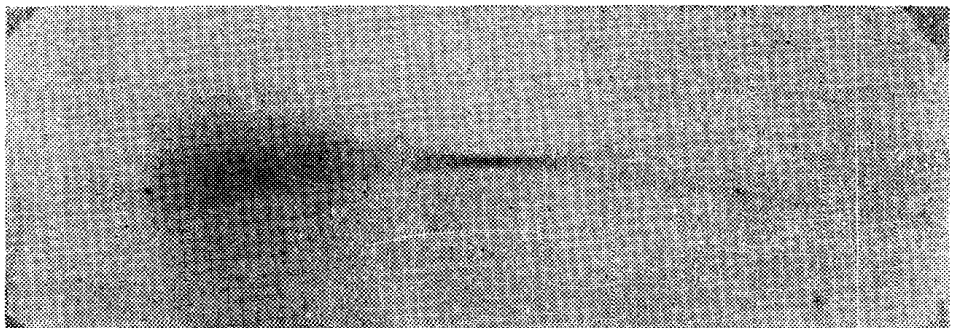

同上を連續撮影

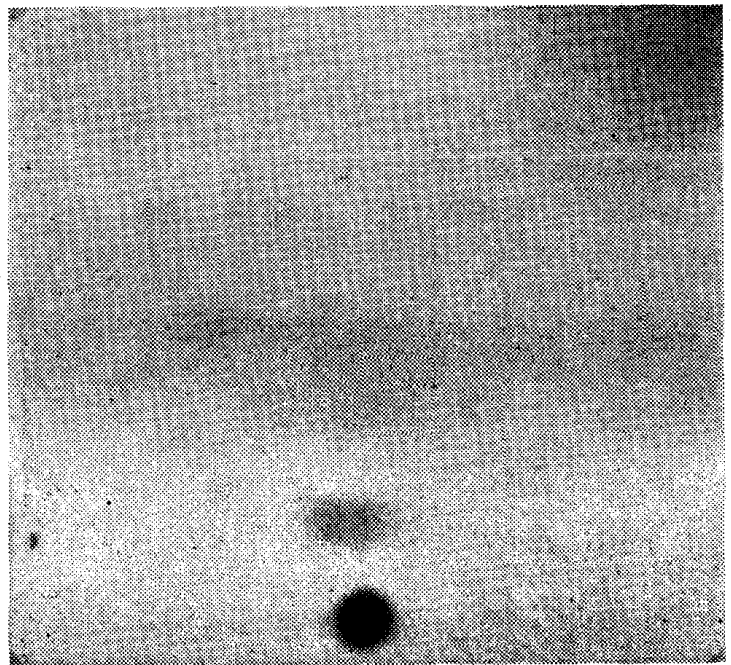

直徑 $4 \mathrm{~mm}$ の銅球を $10 \mathrm{~m}$ の等間隔は置き $40^{\circ}$ で連續撮影
驗は極めてアイマイでその裝置の「ガタ」とか「ブ レ」とかが分らないので精度試驗とはいえない，正 確な精度を有する裝置は第 8 圖 (A) の如く試驗 (1) の場合 Line のなす角 $\theta$ 岋左右同角度をなL, 页連 續移動のものは（B）の如く断面點を除き院影は充 分に抹殺さ放且抹殺像に昰みがなく直線本行になつ ている。

この椂な結果が得られた場合始めて「がタ」「ブ レ」の無い高精度の裝㯰といら事が出來る。

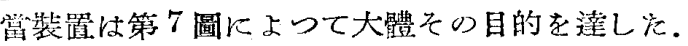

\section{結}

A 長 所

1. 製作費極好僅少。

2. 容積が小さいので何處にでも置ける。

3. 䁈效焦點が小さいので保銃な继面像を 得る一佟件老滿たしている。

B 短 所

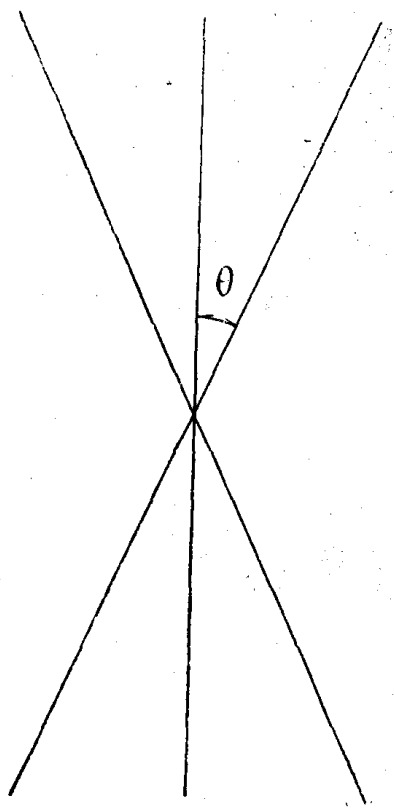

(A)
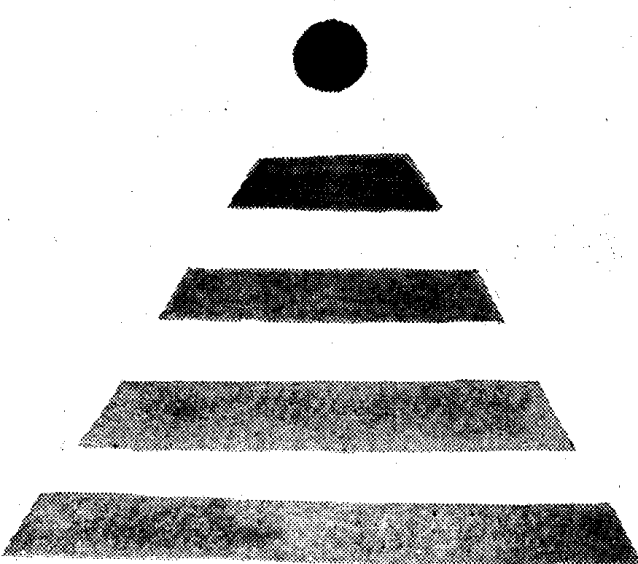


1.木製品のため高精度を望むことがむつかしい.

2. 重鍾運動裝置がない方め操作には熟練を要する。

3 . 撮影時間が長い。

以上の如く一流 Maker 製品に比しいろいろの短所 があるが筫用して差支えない様である。

何最後に此の裝置で撮影し觉寫蒙を揭げて和くので 大力の批判，御叱正並びに御指導を賜われば幸甚に思 います。

終りに臨み御校閱を戴い炎當院長内藤三郎博士・・終 始御協力御指管を戴いた賞院内科部長服部一郎及津田
稳の兩博士，並に製作に御盡力下゙さつ学肢科，營䜌 の職員一同，日本敚療福岡營業所職員の方々に心から 感謝つ意を表します。

\section{考文文䘞}

深津久治：東芝 X線資第；䊅（昭26).

高尾忠美：島津評論 6,15:3 (昭 24 )。

藤本慶治，佐野博也："6,162("). 大日本レントグン製作所研究部參考資料 5 (昭念)。 $S(")$.

\title{
簡易斷層間接撮影裝置の考案
}

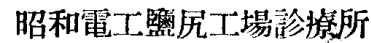 \\ 河 西 袈 装 吉
}

\section{1)考案經 維}

奨通のX線寫点では身體各部の粗織が重骨して立體 感在なくし, 本面に描出される結果胸部等厚き臟器の 場合不必要な肋骨や心歲の影像を覆い敦斷を困奞なら しめている.

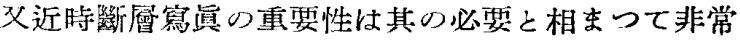
に增大しつつあるが，非常に高儨にして特殊醫療機關 にいみ設惪されて扣る現況であり，當診療所に於ても 其の必要性を痛感されながら經濟的な面で賽現出來な かつたのであります。

從來の断愿寫這は患者の空洞の存在すると思われる 深さについて其の上下等を四ッ切〜ハツ切のフィルム にて撮影其の空洞の位置及び大いさを知つたのである

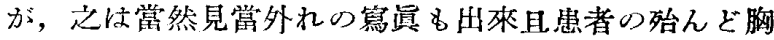
部各曆を撮影乚，影断すると云ら事はフイルムの消費 が进だしく，經濟的にも困難である。次が缺點を克服 するには間接撮影法に上る外なるものと信ずる。

侗装犆が简易にして且安筧に設置出來るとしたなら ば非常に利用價值も多くなり，結核猃断治療に一段と 進步する事と信ずる，依而既設のレントゲン装置に既 設ひ $6 \times 6$ 間接撮影裝犆を利用出來る方法を考案，昭

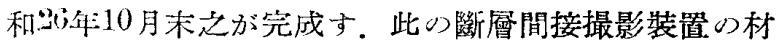

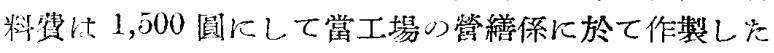
り.

\section{2）原理}

任意の斷面を管球の焦點とフィルムが運動方向を異に して水本の聯動運動をなす法にして值接撮影用フイル

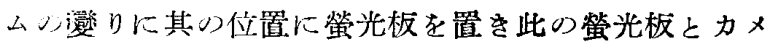
ラと基に斯かせば螢光板に寫る像をキャッチ撮影す 当方法穽り。

\section{3)雷驗}

賞䧐療所レントゲン裝置は大道慗作 $100 \mathrm{~mA} 6 \mathrm{~kW}$ 水冷式管球自己整流据置䧐察用，閒接撮影暗箱山東京 芝浦㱔，カメラ沬東京精機光學裴 X-Ray Canon $6 \times 6$
判に本機械を裝置したるに充分診断價值ある寫黄を得 支り.

撮影條件は距離 $70 \mathrm{~cm}, 40 \mathrm{~mA}, 84 \mathrm{kV} 2.0 \mathrm{~S}$ にして

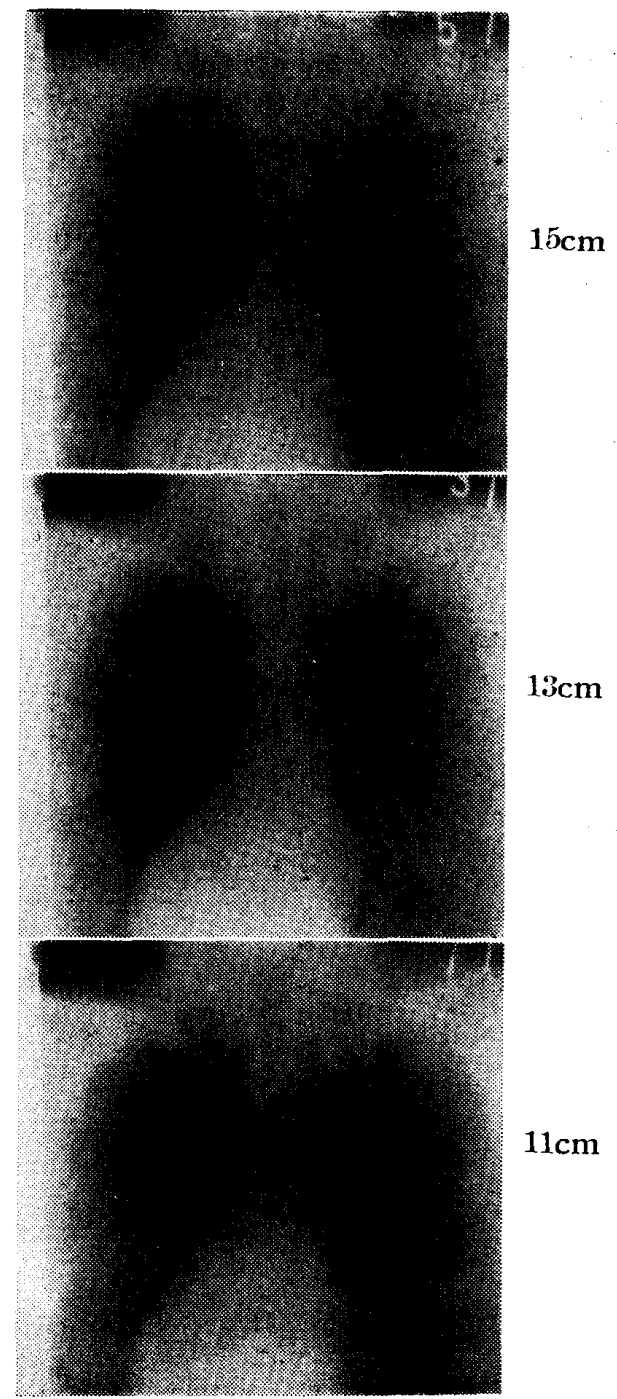

